\title{
Study on Development Strategies of Remote Vocational Education
}

http://dx.doi.org/10.3991/ijoe.v10i6.3804

\author{
Peijiang Chen \\ Linyi University, Linyi, China
}

\begin{abstract}
Remote vocational education is the combination of remote education and vocational education, which plays an important role in training and lifelong education. The main models of remote vocational education in several developed Western countries are analyzed, and their advanced experiences are summarized. Using Linyi City in China as an example, the problems of current remote vocational education in China are focused on, especially in the view of government management, social recognition, remote training, professional settings, and the exchange between teachers and students. Suggestions and countermeasures are put forward to promote the speedy and orderly development of remote vocational education in China. The results of a satisfaction survey show students are satisfied with the teaching quality of remote vocational education and their employment abilities are improved.
\end{abstract}

Index Terms-Remote education; Vocational education; Teacher-student commutation; Virtual experiment

\section{INTRODUCTION}

Vocational education is a special type of education, which is mainly shown in its training objectives and training models. It has strong professional pertinence and is career-oriented. It calls for a training mode that combines industry and teaching and requires that the education content be based on professional knowledge, professional skills, and professional attitude.

Remote education, an education type parallel to traditional school education, can break through the restrictions of time and space. The revolutionary advances of information technology provide more opportunities for the development of remote education, making modern remote education a breakthrough in the education system in China. It is beneficial for promoting the popularization and development of vocational education [1].

Because of the development of the economy and society, China urgently needs to train a large number of application-oriented, practice-focused, skilled employees. Therefore, the objectives and scope of vocational education should be expanded. In this background, the construction and development of remote vocational education are key issues for building a learning society and for a achieving lifelong engineering education. On the basis of analyzing the models of remote vocational education in developed countries, this paper uses Linyi City as an example to analyze the main problems in China and to propose corresponding countermeasures that can be referenced for the healthy and orderly development of remote vocational education in China.

\section{Model AnAlysis OF REMOte VocAtionAL EDUCATION}

In recent years, remote education and vocational education have been integrated and optimized in many aspects. Remote vocational education in developed countries has advanced very well and has made some achievements, as seen in the following discussions

\section{A. Community college in America}

America leads the way in remote vocational education and has formed a relatively complete education system. The community college plays a role as the main force and is seen as the best example of blending higher vocational education and remote education, offering training for a large number of outstanding technical students. The features of the community college include flexibility, practicality, prospect for economy, etc. A representative example is Saint Petersburg College.

The learners at the community colleges have flexibility in choosing how they learn. The programs can take the form of full-time study or remote learning in the students' spare time. The college offers credit courses and noncredit courses. Additionally, the teaching content is updated in a timely manner.

The community college uses a variety of conditions to develop skills. The students can acquire practical ability through campus training, complete simulation practice through information technology, and get real experience through enterprise practice. The technical training model is shown in Fig. 1. The learners can also go to a university for further study after receiving vocational training and obtaining degrees [2].

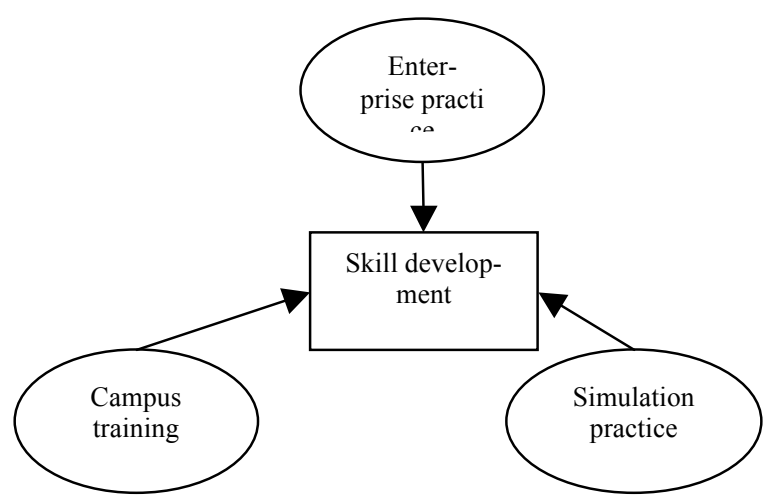

Figure 1. The technical training model of remote vocational education of community college in America 
In addition, remote vocational education in America is sensitive to the changing trends of the labor markets, the supply-demand relationship and the characteristics of students. Remote vocational education combines remote education and traditional campus education organically, takes advantage of the particular strengths of remote education, emphasizes the characteristics of vocational and technical education, and promotes the development of vocational education in the United States.

\section{B. Open university in England}

England also attaches great importance to remote vocational education. The government provides technical support for remote vocational training. The educational resources are fully used, and a vocational education network system with distinctive characteristics has been established.

The Open University in England is a new type of university that combines remote education and an open educational forum in higher education. With modern teaching techniques, a novel learning model and complete professional setting, the University has set up a large number of courses for undergraduates, graduates and non-degree students. The new technology use has improved the teaching quality and increased the learning opportunities for students. These technologies include computer conferencing, e-mail, DVD, Internet, and so on. The university has also provided service support for students learning [3].

In terms of curriculum, there are both long-term courses and short-term courses. In the teaching process, the main model is individualized learning, supplemented by group learning. The Open University has a good operation management mechanism and a strict examination system, which provide solid assurance for carrying out remote vocational education.

\section{Technical and further education in Australia}

Due to its vast territory and scattered population, Australia also pays special attention to remote education. Central Technical and Further Education (TAFE) is a national technical education system, aimed at job-hunting and developing ability; its ultimate goal is employment upon graduation. It combines technical education and continuing education and links academic education and job training. TAFE is designed to meet the needs of economic development and to satisfy the needs of learners hunting jobs. It adopts flexible education to train technical personnel [4].

The high school students in Australia accepting TAFE education account for about $70 \%$, with more than half adopting distance learning. At the same time, TAFE provides remote vocational and technical training and continuing education for a period ranging from two weeks to three years for working people in community, issuing corresponding technical and vocational certificates.

Remote education in Australia has very extensive curricula, which provide flexible and open courses to meet the needs of different groups of people receiving education. The national remote vocational education has adopted a unified course system to ensure that the remote students and school students have the same quality of education. Each school recognizes the credits mutually. Remote education students are treated as the full-time students studying within campus, and the society treats them equally [5].

\section{Open remote education in Japan}

The Japanese government has set up a communication technology promotion association and established a project called E-Japan [6]. There are two types of remote education in Japan: open remote education represented by the Open University of Japan and communication-based remote education in a full-time university. They each have their own characteristics, reflecting the strategies and methods in different aspects of remote education. Meanwhile they cooperate and share resources with each other and promote the overall prosperity and development of remote education in Japan.

The Open University of Japan has vigorously developed remote education, creating flexible and practical teaching. The majors are dynamically adjusted based on investigation of community needs. To improve the basic qualities of the national people, there are many general majors in the university. It offers a variety of teaching media, and the courses are transmitted mainly through radio, television and the Internet [7]. The new information technologies have played very significant roles in promoting the remote vocational education.

\section{Problems of Remote VocAtional EducAtion IN LINYI CITY}

At present, remote vocational education has developed very quickly in China, making remarkable achievements in terms of hardware equipment, digital network construction, and teaching resources, and a modern distance education network was initially formed. More and more people have come to understand the benefits and convenience of using a modern means of remote education to learn, and it plays an increasingly important role in training talents. However, due to the late starters in remote vocational education, China has encountered some issues. Using Linyi City as an example, the rest of this paper analyzes the problems in the development process of remote vocational education in China.

\section{A. Lack of policies and regulations, imperfect management system}

Although the Chinese government proposed the concept of remote vocational education and also provided considerable support, most of it was at the level of projects. The laws and regulations relevant to modern remote vocational education are mainly departmental regulations. It lacks deeper laws and regulations on lifelong learning.

In addition, the relevant agencies and experts do not pay enough attention to research on the characteristics of modern distance education, which cause a one-sided and different understanding of the object of remote education. With the rapid development of modern remote education, the problem of lagging construction for policies and regulations is increasingly prominent [8]. It has become the primary factor restricting the healthy development of remote vocational education in China.

\section{B. Insufficient social attention and lower recognition}

To build a lifelong education system, the technological advantages of radio, television, digital media and computer network should be used whenever possible. Integrating 
various types of educational resources, establishing an open university, and implementing remote education can provide more clear thinking and policy support for the development of remote vocational education.

But from a practical point of view, more students believe that remote vocational education is only a way to quickly get a diploma. They do not give sufficient attention to remote vocational education, and the direct consequence is that they do not have a serious and earnest attitude toward learning. In addition, the employers discriminate against the students from remote vocational education programs and believe that there is a great gap compared with the traditional college students. Then some employers set up barriers in employment and do not recognize the remote education diplomas [9]. The disagreement among students, employers, and the social environment has restricted the development of remote vocational education in China.

\section{Inadequate remote resources, lack of training equipment}

In recent years, the Chinese government has increased the investment in regional education, but the problem of inadequate office expenses in some remote education institutions has not been fundamentally resolved. The school conditions need to be improved. The computer network provides people with massive knowledge, but the web-courseware resources are not suitable for learning. The lack of high-quality remote learning resources is an important contradiction that currently restricts the development of remote education.

In particular, remote vocational education requires good practical training conditions, but the reality is that the training equipment is insufficient and the training base construction is lagging. In addition, in the practice of teaching remote vocational education, some non- traditional equipment is needed and the students need to participate in the teaching process. It requires two-way transmission of information and practical devices, which makes it more difficult than ordinary classroom teaching. Additionally, most modern remote education in China is confined to arts and management majors [10]. These factors result in weak teaching; a considerable number of students cannot learn the actual skills and there are big differences between the quality of the trained students and the requirements of the enterprises. As a consequence, the majority of students can only engage in basic operations after they graduate, fundamentally affecting the operating level and overall quality of remote vocational education students.

\section{Don't contact with market closely, unreasonable professional setting}

Currently, remote vocational education in China is still government run, although there are some cooperative models with companies, such as for order training, but close and deep cooperation is scarce, leading to inadequate educational vitality and creating a weak attraction to students and employers.

There is a large gap between the disciplines and market demand and a lack of schools and participating disciplines. The favorite majors of remote vocational education, according to the investigation in Linyi City, are shown in Fig. 2. If the remote vocational education does

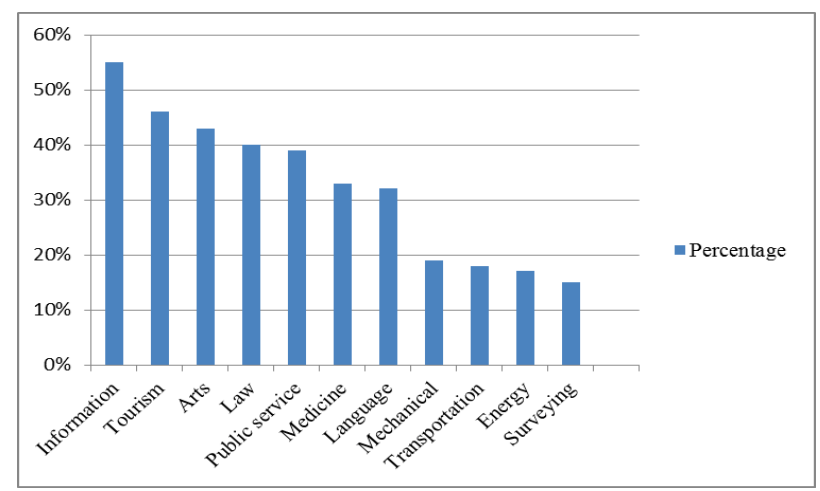

Figure 2. The most favorite majors of remote vocational education according to the investigation results in Linyi, China

not fit the demands of skilled personnel trained in the content, training mode and course structure, the students will not receive high praise from employers [11].

\section{E. Service system is imperfect, lack of exchange between teachers and students}

In the teaching process, the relationship between the teachers and students is most important and basic. A good teacher-student relationship is beneficial to mobilize the enthusiasm, initiative, and creativity of both teachers and students, and it is conducive to creating a relaxed and positive teaching atmosphere. Similarly, communication between the students and teachers is an important part of remote vocational education [12].

But in current remote vocational education, teachers often only provide relevant teaching information, course content, homework submission, examination, and some support services. Communication between the two parts is really lacking. Without the guidance of teachers, it is difficult to build and develop the capacity for independent learning among the students.

In summary, it is easy to see that there are certain problems in China's remote vocational education. The teaching quality of its remote vocational education is not satisfactory, and it cannot meet the practical needs for economic development. Therefore, it is essential to take appropriate measures to solve these problems.

\section{DEVElopment STRATEGIES OF REMOte VOCATIONAL EDUCATION}

On the basis of analyzing the current status of remote vocational education in developed countries, referencing their advanced experience, and considering the shortcomings of remote vocational education in Linyi City, Shandong province, China, from the view of societal needs, some suggestions and countermeasures are put forward to meet the development of remote vocational education.

\section{A. Suitable laws and regulations, standardize remote vocational education}

A suitable legal system and institutional guarantee are the premises for smooth development of remote vocational education in developed countries. In order to provide a legal basis for remote vocational education and to promote normalization and predictability of the educational operation, it is necessary to strengthen the construction of legal rules and laws related to remote vocational 
education. The implementation, management and development of remote vocational education should be planned to ensure the country can regulate remote vocational education in a macroscopic world.

All levels of the government and the educational institutions should develop policies and principles for remote vocational education to meet the actual needs of different regions. They must adjust the remote education management system, optimize the allocation of educational resources, strengthen their cooperation for running schools, and build an integrated educational model of traditional face to face education and remote education.

In planning modern remote vocational education, it is necessary to take into account academic education as well as all forms of non-academic training and to emphasize the roles of the governments, education departments, schools, businesses and other community organizations in developing remote vocational education. Remote education should highlight the important points in practice, give priority to the rural areas, gradually form an open education network, and adapt to the variety of the learning requirements.

\section{B. Societies recognize, create favorable environment for remote vocational education}

To create a learning society is a major component in the reform of modern education. Because of its distinctive personalities (such as occupation, practicality, etc.), it is important to improve the quality of students and to enrich the education types.

Education authorities at all levels need to increase people's awareness of remote vocational education and improve the inclusion of companies and employers, getting rid of discrimination regarding remote education, to create better conditions for the development of remote vocational education, especially in remote areas.

\section{Share resources, make full use of virtual labs}

Through unified planning, the government should promote the rational allocation of software and hardware resources for remote education and maximize the social benefits. The government should accelerate the pace of establishing educational information resources and should gradually build an open and dynamic shared library of information resources for vocational education. Schools should introduce the latest teaching resources and abandon the outdated ones [13].

Virtual experiments should be implemented based on information technology, making it possible for remote practical teaching to solve the problems between practical education and remote education to a great extent [14]. The experimenters may enter the virtual laboratories at any time, which not only provides practice conditions and technical support for remote vocational education, but also provides students with more, newer, and better equipment. The application of virtual laboratories and virtual experiments makes the remote practical teaching more accurate. It plays an important role in strengthening skills training for remote vocational education students. The virtual training platform is shown in Fig. 3. Making full use of virtual experiments through professional courses and developing more and better simulation experiments can greatly improve the practical skills of remote education students.

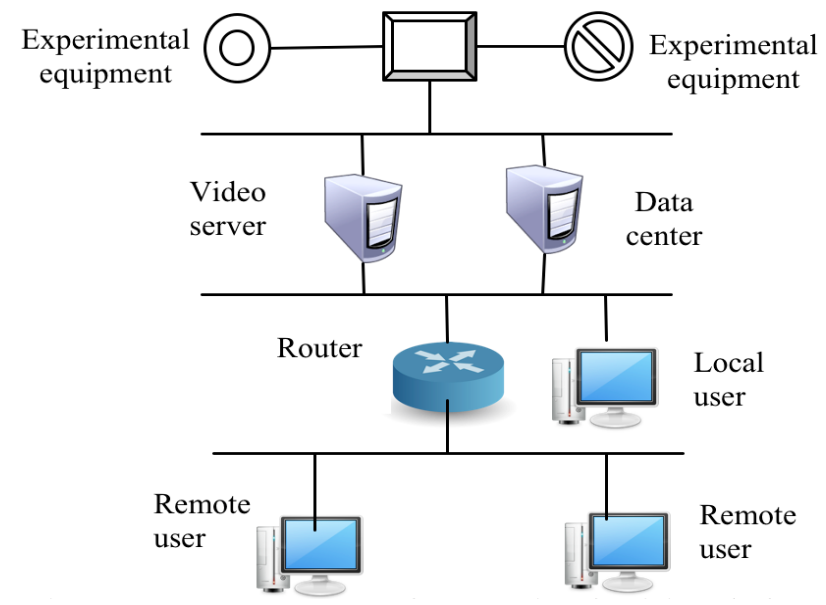

Figure 3. System structure of remote virtual training platform

\section{Take employment as the orientation, set up characteristic majors and courses}

Educational organizations at different levels foster scientific orientation, promote order training, deepen the mode of combining production and teaching, and enhance the vitality of remote vocational education to adapt to the requirements of the labor markets. Remote vocational education should meet the needs of the national economic pattern and industrial structure. Schools should communicate with enterprises and institutions and should understand the labor demands of enterprises as well as the learning needs of working professionals by focusing on the labor market.

The government should encourage and support that remote education can respond quickly according to market needs, transforms traditional majors, and develops new majors in accordance with market demand. Schools should hold onto the principle of being service-aimed and employment-oriented. They must adjust their structure based on the community and market, highlight the characteristics of the local economy and train to meet the professional technical talents.

\section{E. Apply various communication tools to improve service channels}

In the particular process of remote vocational education, it is necessary to find a student-centered model and to increase the information service channels to keep communication between teachers and students open [15]. The multimedia technologies and information technologies should be fully applied to achieve remote teaching, such as commonly used video conferencing, livetransmission classrooms, BBS bulletin boards, email, and so on.

To establish a harmonious relationship, the teachers need to take each opportunity to communicate with students [16]. To capture the students' interest, the teachers can use dynamic technology to present the teaching content to the learners. They can also use other modern methods to communicate with students to improve mutual understanding and strengthen their attention to improve the study effect. 


\section{EFFECTIVENESS AND SATISFACTION SURVEy OF REMOTE VOCATIONAL EDUCATION IN LINYI}

To test the implementation effect of remote vocation education and further improve the teaching quality, the students' satisfaction was surveyed. The investigation was divided into six first class indicators and seventeen second class indicators, as shown in Table 1. Each second class indicator had five points, but their weights were different.

For the survey, 500 questionnaires are sent out, and 485 questionnaires were received, of which 477 were valid. The age distribution of the respondents is shown in Fig. 4.

The degrees in vocational education are mainly an associate's and a bachelor's. Measured by shares, this survey has good representativeness. The survey results are shown in Table 2.

Through analysis of the investigation results, it can be seen that the student think highly of the effectiveness of remote vocational education in Linyi City of China, but there are some differences in indicators. In general, the students participating in the remote occupation education said they obtained benefit, especially their employment options and career prospects, and they recognized the teaching quality and conventional management. But the students presented their own views on the hardware of remote education, especially the experiment and practice segments. This survey reflects that they look forward to convenient remote learning.

\section{CONCLUSIONS}

With the continuous development of the social economy, modern remote vocational education is facing dual pressures brought by the market and the needs. The governments, enterprises and educational training organizations should strengthen cooperation and promote balanced development of remote vocational education through the innovation of technologies and mechanisms.

Remote vocational education is a new form combining remote education and vocational education. It is necessary to integrate practicality, professionalism, and applicability of vocational education. Modern information technology should be used to establish the most suitable remote vocational education environment, promote healthy development, improve the quality of workers, and train a large number of application-oriented individuals.

In summary, remote vocational education in China has been explored, and balanced and orderly development is the greatest concern of the teachers and educators. The most important task now is the integration of remote education and vocational education at the national level and in the academic units

\section{REFERENCES}

[1] F. Hu, Y. Xu and F. Gao, "On the Meaning and Function of Distance Vocational Education in China", China Educational Technology, no .11, pp. 36-39, 2008.

[2] S. Mu and J. Wu, "Research on the Implementation of International Remote Vocational Education", China Educational Technology, no .2, pp. 47-51, 2010.

[3] M. Zhang and X. Ding, "E-learning at the Open University in $\square . K$ and Enlightenment to China", Open Education Research, no. 3, pp.15-17, 2003.
TABLE I.

INDICATORS OF SATISFACTION SURVEY

\begin{tabular}{|c|l|}
\hline First class indicator & \multicolumn{1}{|c|}{ Second class indicator } \\
\hline Enrolling & Enrollment propaganda, processing service \\
\hline Teaching team & $\begin{array}{l}\text { Managerial staff, face-to-face teachers, } \\
\text { experimenter }\end{array}$ \\
\hline $\begin{array}{c}\text { Remote teaching } \\
\text { condition }\end{array}$ & $\begin{array}{l}\text { Network platform, teaching material, } \\
\text { remote experiment }\end{array}$ \\
\hline Learning support & $\begin{array}{l}\text { Answering question, experiment instruc- } \\
\text { tion, online communication }\end{array}$ \\
\hline Examination & $\begin{array}{l}\text { Examination organization, examination } \\
\text { discipline }\end{array}$ \\
\hline Employment & $\begin{array}{l}\text { Ability enhancement, job recommend, } \\
\text { employment quality }\end{array}$ \\
\hline
\end{tabular}

TABLE II.

RESULT OF SATISFACTION SURVEY

\begin{tabular}{|c|c|c|c|}
\hline Indictors & $\begin{array}{c}\text { Average } \\
\text { score }\end{array}$ & $\begin{array}{c}\text { Highest } \\
\text { score }\end{array}$ & $\begin{array}{c}\text { Lowest } \\
\text { score }\end{array}$ \\
\hline Overall satisfaction & 4.205 & 5.00 & 2.95 \\
\hline Enrolling & 3.953 & 5.00 & 3.19 \\
\hline Teaching team & 4.356 & 5.00 & 3.04 \\
\hline Remote teaching condition & 3.991 & 4.92 & 2.86 \\
\hline Learning support & 4.023 & 4.98 & 1.52 \\
\hline Examination & 4.380 & 5.00 & 2.66 \\
\hline Employment & 4.377 & 5.00 & 4.04 \\
\hline
\end{tabular}

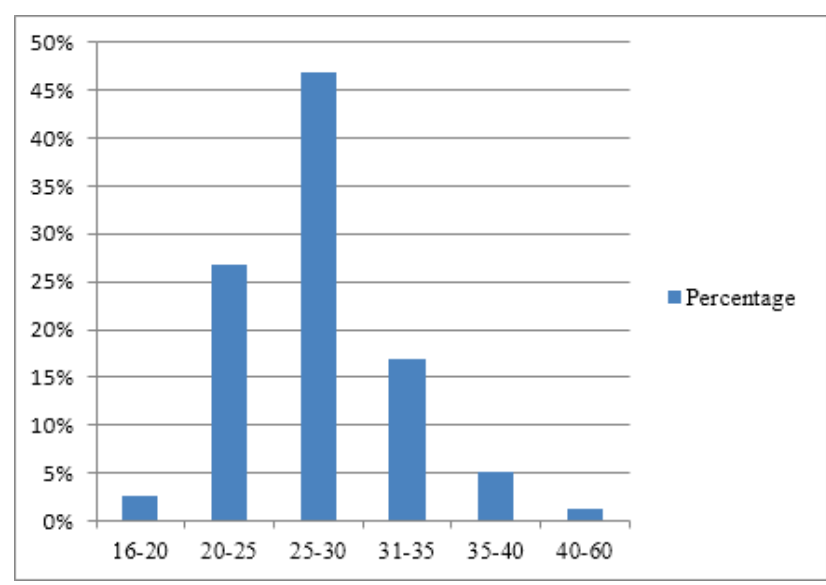

Figure 4. Age distribution of the respondents of satisfaction survey

[4] Z. Li and H. Liu, "The characteristics and Enlightenment of the Remote Vocational Education in Australian", Continue Education Research, no. 2, pp. 104-106, 2010.

[5] Y. Lu, "Australian Distance Vocational Education and Its Enlightenment", Journal of Tianjin Radio \& TV University, vol. 15, no. 2, pp. 68-69,73, 2011.

[6] H. Li, "Present Situation and Characteristics of Remote Vocational Training Abroad", Distance Education in China, no. 11, pp. 7376, 2007.

[7] Z. Chen, "Open remote Higher Education and its Enlightenment in Japan”, Journal of Guangxi Radio and TV University, vol. 17, no. 3, pp. 29-30, 2006.

[8] C. Sun, "View of Science and Development: New Visual Angle of Modern Distance Education Existing Problem, Development Tendency and Countermeasure Research", Modern Distance Education, no. 5, pp. 13-17, 2005.

[9] Y. Shan. "Development Status of Remote Vocational Education in Hebei Province", Education Circle, no. 15, pp.137-138, 2013.

[10] M. Zhao and Y. Wu, "Introduction to Practical Teaching Solution of the Remote Vocational Education”,. China Management Magazine, no. 23, pp. 586-587, 2012. 
PAPER

\section{STUDY ON DEVELOPMENT STRATEGIES OF REMOTE VocATIONAL EDUCATION}

[11] X. Lu and F. Hu, "The Investigation and Analysis to Demand of Remote Vocational Education for Vocational College Students, Based on the Part of the Higher Vocational Colleges in Shandong Province", China Educational Technology, no .8, pp. 49-53, 2019.

[12] Y. Gong and F. Tang, "The Development of Higher Education Remote-Distance Programs Based on Internet", Journal of Luoyang Normal University, vol. 32, no. 2, pp. 116-118, 2013.

[13] W. Wang, "The Status analysis of Remote Vocational Education in China", [J]. Chinese Vocational and Technical Education, no. 28, pp. 10-14, 2006.

[14] S. Huang, J. Yang and C. Ning, "The Construction of Public Training Platform for Open and Distance Vocational Education", Journal of Suzhou Vocational University, vol. 24, no. 2, pp. 31-33, 2013.

[15] G. Xu, Z. Xu, A. Fu, G. Liu and M. Ding, "On Effective Strategies of Distance Education Learning Support - Taking SHTVU Min- hang Branch as an Example", Journal of Jiangsu Radio \& Television University, vol. 20, no.2, pp. 40-44, 2009.

[16] Z. Huang, "Thinking of Building Harmonious Relationship Between Teachers and Students in Modern Remote Education", Journal of Xinjiang RTVU, vol. 12, no. 4, pp. 18-20, 2007.

\section{AUTHORS}

Peijiang Chen is with the School of Automobile, Linyi University, Linyi, Shandong, 276000, China (e-mail: chenpeijiang@163.com).

This work was supported by the Social Science Research Project of Linyi, Shandong Province, P. R. China (No. 2012SKL341). Submitted, 26 April 2014. Published as resubmitted by the authors on 25 October 2014 